TITLE:

\title{
Studies on Electrode-slurry for Lithium-ion Batteries(Abstract_要 旨)
}

$\operatorname{AUTHOR}(\mathrm{S}):$

Takeno, Mitsuhiro

CITATION:

Takeno, Mitsuhiro. Studies on Electrode-slurry for Lithium-ion Batteries. 京都大学, 2017, 博士(工学)

ISSUE DATE:

2017-05-23

URL:

https://doi.org/10.14989/doctor.k20580

RIGHT:

学位規則第9条第2項により要約公開; 許諾条件により要約は2018-0101に公開; 許諾条件により要旨は2017-06-01に公開 
( 続紙 1 )

\begin{tabular}{|l|c|l|l|}
\hline 京都大学 & 博士 $($ 工 $\quad$ 学 $)$ & 氏名 & 武野 光弘 \\
\hline 論文題目 & $\begin{array}{c}\text { Studies on Electrode-slurry for Lithium-ion Batteries } \\
\text { (リチウムイオン電池電極用スラリーに関する研究 })\end{array}$ \\
\hline
\end{tabular}

(論文内容の要旨)

本論文は、リチウムイオン電池の合剤電極の性能に最も重要な影響を与える電極スラリーに関 する研究について、レオロジー解析と交流インピーダンス法を組み合わせて、電極スラリーを調 べた研究の成果をまとめたものであり、序論および 5 章で構成されている。

序論では、リチウムイオン電池の内部抵抗について概説している。さらに、出入力特性を向上 させるためには、電極の電子輸送に関する抵抗が十分に小さいことが求められることを示し、こ の電子輸送抵抗と電極スラリーとの相関性について記載している。電極スラリーは電池性能に直 結するものであるが、その研究報告例は少ない。そこで、電極スラリーの重要性をあらためて示 すことにより、本研究の目的と意義を述べている。

第 1 章では、リチウムイオン電池電極用スラリーの電子伝導性を評価する手法を新しく開発し た内容をまとめている。電極スラリーは、絶縁体の分散媒に導電剤が不連続で分散している構造 のため、直流法では測定できない。そこで、交流インピーダンス法を用いる手法を開発した。電 極面積と、スラリーの体積を既定して測定を行い、ナイキストプロットから電極スラリー中の電 子伝導に由来する成分を抽出している。これにより、電極スラリーの体積抵抗率を計測できるこ とを見出している。また、電極スラリーの電子伝導性は、導電剂として用いるアセチレンブラッ ク（AB）の配合量に応じて向上することを示している。さらに電極スラリーのレオロジ一解析に より、電子伝導性が電極スラリー中の AB のネットワーク構造により発現することを明らかにして いる。ここで開発した手法を用いることで、電極スラリーの段階で、電池特性と相関する電子抵 抗を評価することが可能になることも示している。

第 2 章では、種々の導電剤炭素材料が電極スラリーの電子伝導に与える影響を検討している。 導電剤が電極スラリー中および合剤電極内でどのような電子伝導経路を形成しているかに注目し た。ストラクチャが非常に発達している $\mathrm{AB}$ 、繊維状で長距離の伝導経路が期待できる気相成長炭 素繊維 (VGCF)、他の炭素材料と比べて良導体である微小黒鉛材料の電極スラリーや合剂電極の抵 抗を、第 1 章で開発した手法を用いて調べ、形状や電子伝導性の違いや挙動の関係について調べ ている。その結果、電極スラリーでは、黒鉛が最も電子伝導性が低く、AB と VGCF は同程度であ った。また、黒鈶は添加量を増加しても体積抵抗率は大きく変化せず、AB と VGCF ではその変化 が顕著であった。これは、AB ではアグリゲートからなるアグロメレートが、VGCF では炭素繊維の 絡み合いによりそれぞれ導電ネットワークが形成されるが、黒鉛では電子伝導経路が電極スラリ 一中では増加していないことをレオロジー解析と合わせて明らかにしている。また、合剤電極の 電子伝導性は、導電ネットワーク構造がそしい場合、体積抵抗率のばらつきとして現れるが、電 極スラリーで体積抵抗率が高い黒鉛を用いた場合では、実際の電池系を想定して圧縮すると、AB を用いた場合よりも合剤電極では体積抵抗率が小さくなる場合があるため、電極スラリーの状態 で導電ネットワーク構造を評価することが重要であることを明確にしている。

第 3 章では、リチウムイオン電池正極合剂電極の混合プロセスが電池性能に与える影響について 調べている。 $\mathrm{AB}$ と活物質を高粘性の状態でせん断力をかけて混合寸る場合と、 $\mathrm{AB}$ と活物質を低粘性 の状態で別々に分散して、混合するプロセスの比較を行っている。高粘性の状態で混合すると電池の 内部抵抗が高くなり、電極スラリー中での導電剂の微細構造が混合プロセスにより大きく異なること が示されている。また、この場合、電極スラリーや合剂電極の電子抵抗も高く、レオロジ一解析の結 


\section{\begin{tabular}{|l|l|l|l|}
\hline 京都大学 & 博士（ 工 学） & 氏名 & 武野 光弘 \\
\hline
\end{tabular}}

果から、 $\mathrm{AB}$ のネットワーク構造が破壊されていることが明らかにしている。合剤電極の走査型電子顕 微鏡観察から、 $\mathrm{AB}$ の大きな凝集塊が確認され、 $\mathrm{AB}$ の静電反発で分布していたアグリゲートが、高い せん断エネルギーで衝突して凝集することを示した。一方で、 $\mathrm{AB}$ と活物質を低粘性の状態で別々に分 散した後、混合した場合では、最終的に高粘性となるが、導電ネットワーク構造が発達していた。こ れらにより、混合プロセスの違いを電極スラリーの段階で評価し、電池の内部抵抗を予測できること を見出している。

第 4 章では、電極スラリーの調製中間段階の電子伝導度を解析している。電極スラリーの調製プロ セス中間段階での導電ネットワークの変化は、合剂電極の抵抗では捉えられないが、本手法では混合 による変化を捉えることができ、電池の内部抵抗との相関も確認できた。また、固形分濃度の違いで の体積抵抗率の変化を解析することで、電極スラリーの導電剂の見かけの体積に応じて電子伝導性が 変化することを見出し、任意の固形分濃度の電子伝導性を混合途中で解析できることを示している。

第 5 章では、合剂電極における導電剤の電子抵抗が電池の内部抵抗としてどのように影響するかを 詳細に解析している。導電ネットワーク構造の異なる $\mathrm{AB}$ 、微小黒鉛、およびそれらを混合した導電剂 を用いた合剂電極の内部抵抗について、直流抵抗評価法と交流インピーダンス法を用いて調べた。対 称セルの温度違いでの交流インピーダンス解析を用いることで、電子移動と、電荷移動に由来する抵 抗の分離が可能であることを見出し、また、合剂電極における活物質の導電剂の接触抵抗が電池特性 に与える影響を、伝送線モデルを用いて明らかにしている。 
(論文審査の結果の要旨)

本論文は、リチウムイオン電池の合剂電極の性能に最も重要な影響を与える電極スラリーに 関する研究について、レオロジー解析と交流インピーダンス法を組み合わせた方法による研究を まとめたものであり、主な成果は次のとおりである。

1.リチウムイオン電池電極用スラリーの電子伝導性を評価する手法を新しく開発した。電極 スラリーは、絶縁体の分散媒に導電剤が不連続で分散している構造のため、直流法では測定でき ない。そこで、交流インピーダンス法を用いる手法を開発した。さらに、この手法と電極スラリ 一のレオロジー解析により、電子伝導性は電極スラリー中の導電剂であるアセチレンブラックの ネットワーク構造により発現することを明らかにした。

2. 導電剂の炭素材料を変えた電極スラリーを調べた結果、スラリーの体積抵抗率は電子伝導 性が最も高い黒鉛が最大の值を示し、気相成長炭素繊維とアセチレンブラックの抵抗率は同程度 に低いことが分かった。これらの結果より、スラリー中の導電ネットワーク構造を評価すること が、電極設計には重要であることが示した。

3. 導電剂と活物質を混合するプロセスにより、スラリーの電子伝導性が異なることを見出し、 混合プロセスを最適化することの重要性を示した。

4. 電極スラリーを調製する中間状態での電子伝導性の解析を行った。その結果、電極スラリ 一中の導電剤の見かけの体積に応じて電子伝導性が変化することを見出し、任意の固形分濃度の 電子伝導性を混合途中で解析できることを明らかにした。

5. 電極スラリー中の導電ネットワークを評価した後に、合剤電極を作製し、その抵抗成分に ついて交流インピーダンス法により調べた。その結果、対称セルを用いることにより、電子移動 と電荷移動に由来する抵抗の分離が可能であることを見出し、また、合剤電極における活物質と 導電剂の接触抵抗が電池特性に与える影響を、伝送線モデルを用いて明らかにした。

以上、本論文では、合剤電極の電子伝導に関わる導電剤の接触や絡みを導電ネットワーク構造と して、電極スラリーの段階で評価できる手法を見出し、これにより電子伝導に優れたリチウムイオ ン電池合剤電極の設計指針を示したもので、新規な学術的知見をともなっている。よって、本論 文は博士（工学）の学位論文として価值あるものと認める。また、平成 29 年 4 月 25 日、論文内容とそれに関連した事項について試問を行って、申請者が博士後期課程学位 取得基準を満たしていることを確認し、合格と認めた。

なお、本論文は、京都大学学位規程第 14 条第 2 項に該当するものと判断し、公表 に際しては、当該論文の全文に代えてその内容を要約したものとすることを認める。

要旨公開可能日： $\mathrm{H} 29$ 年 6 月 1 日以降 